This item was submitted to Loughborough's Research Repository by the author.

Items in Figshare are protected by copyright, with all rights reserved, unless otherwise indicated.

\title{
The moment and technique of Milkman
}

PLEASE CITE THE PUBLISHED VERSION

\section{PUBLISHER}

Oxford University Press (OUP)

VERSION

AM (Accepted Manuscript)

\section{PUBLISHER STATEMENT}

This is a pre-copyedited, author-produced version of an article accepted for publication in Essays in Criticism following peer review. The version of record Clare Hutton, The Moment and Technique of Milkman, Essays in Criticism, Volume 69, Issue 3, July 2019, Pages 349-371, https://doi.org/10.1093/escrit/cgz012 is available online at: https://academic.oup.com/eic/article/69/3/349/5537740?rss=1 and https://doi.org/10.1093/escrit/cgz012.

\section{LICENCE}

CC BY-NC-ND 4.0

\section{REPOSITORY RECORD}

Hutton, Clare. 2019. "The Moment and Technique of Milkman”. figshare. https://hdl.handle.net/2134/36797. 


\section{'The subsoil of our conversation': The Moment and Technique of Milkman}

\section{Clare Hutton, Loughborough University*}

Writing in The Guardian a few hours after Anna Burns's Milkman was awarded the Man Booker prize, Claire Armistead announced that the jury had 'delivered a bombshell' by awarding the prize to a 'boldly experimental' work which was 'not the best novel in contention this year' and a 'consistent outsider in the bookies' odds'. ${ }^{1}$ Book prizes are, of course, designed to elicit such indignant responses. But it has quickly become apparent that Armistead's views do not represent much of a consensus. Milkman has proven to be particularly popular with readers. The publishers have described the demand for the title as 'astonishing' and attributed it to the 'pure quality of the book' as well as 'genuine public affection' for Burns herself. ${ }^{2}$ But it is true to say that few predicted or foresaw Milkman's triumph. In terms of critical writing it is also significant that very little has been written about Burns as an author to date. ${ }^{3}$ Thus this essay, which is in two parts, sketches some initial interpretive strategies for the work. The first part focuses, in particular, on the question of moment in relation to the work, including the moment of the novel's setting, the moment of its formation, the moment of its composition, and the moment of its Booker win. Armistead is one among a number of readers who has complained of Milkman's difficulty and thus the second part of this essay focusses on questions of technique (narrative viewpoint, style, language and lexical choice) because an explication of these interpretive anchors may help to orient future readings. The purpose is to suggest what kind of novel Milkman is, and to work out why the announcement of its win was greeted with surprise and dismay in some quarters, and delight and enthusiasm in others.

\footnotetext{
* With thanks to my students at Loughborough with whom I have enjoyed discussing Milkman, and to my colleagues Ronan Crowley, Deirdre O'Byrne, Nigel Wood and Gillian Wright for their comments.

${ }^{1}$ Claire Armistead, 'Milkman is a Bold Choice', The Guardian, 16 October 2018, https://www.theguardian.com/books/2018/oct/16/milkman-is-a-bold-choice-but-its-unlikely-toplease-booksellers.

${ }^{2}$ Heloise Wood, 'Astonishing Demand for Milkman Continues', The Bookseller, 21 November 2018.

${ }^{3}$ There is a chapter on Burns in a Newcastle PhD thesis (Anthea Cordner, 'Writing the Troubles: Gender and Trauma in Northern Ireland', Newcastle University PhD, 2014). Burns's writing is briefly discussed in Oona Frawley (ed.), Memory Ireland: The Famine and the Troubles (Syracuse University Press, 2014), and Maureen E. Ruprecht Fadem, Literature of Northern Ireland: Spectral Borderlands (New York: Palgrave, 2015).
} 


\section{The Moment of Milkman}

Milkman was published by Faber and Faber, in May 2018. Writing for The Irish Times, Adrian McGinty was the first to review the work, describing Burns as 'one of our rising literary stars', and identifying the setting of Milkman as 'Belfast of the uneasy 1990s'.4 Both statements are a bit imprecise. Burns, born in Belfast in 1962, was 56 when she won the Man Booker, and she had already published two novels: No Bones (2001) and Little Constructions (2007). ${ }^{5}$ No Bones was shortlisted for the Orange Prize for Fiction in 2002 (a prize established to recognize the achievement of female writers) and won the Royal Society of Literature's Winifred Holtby Memorial Prize in 2001.6 In a telling and ironic marketing counterpoint the front cover of the paperback edition of Milkman now being issued by Faber includes the phrase 'Winner of the Man Booker Prize 2018' alongside McGinty's initial judgement ('Impressive... confirms Anna Burns as one of our rising literary stars'). ${ }^{7}$ Burns's position as an established novelist before the advent of Milkman needs to be acknowledged. She was not widely known, and nor did she have an enthusiastic critical following. But she had been writing, and Milkman is not a debut.

Nor is it accurate to describe the setting as 'Belfast of the uneasy 1990s'. The main event of the narrative-the stalking of the eighteen year old female narrator who is referred to variously as 'middle sister', 'middle daughter' and 'maybe-girlfriend'-occurs in the seventies. The narrator tells us this pretty carefully on several occasions, including the second chapter ('this was the Nineteen-seventies', 60), and the third chapter ('It was hatred, the great Seventies hatred.', 96). The first chapter specifies the moment of the work more exactly through a reference to Sigourney Weaver in Alien ('killing the creature in that new film', 8) and a cultural landscape which includes Barbra Streisand, Kate Bush and Freddie Mercury all at the apex of popularity. Together these references imply 1979 as the year in which the stalking occurs, and Burns is more specific later in the work. The narrator is incredulous when she realises that her 'third brother-in-law', is someone who 'didn't know the political problems of eleven years were going on' (58), a more or less clear reference to the beginning of the 'Troubles' in Northern Ireland in October 1968.

\footnotetext{
${ }^{4}$ Adrian McGinty, The Irish Times, 12 May 2018.

${ }^{5}$ Information from https://themanbookerprize.com/news/anna-burns-wins-50th-man-booker-prizemilkman. No Bones (London: Flamingo, 2001) and Little Constructions (London: $4^{\text {th }}$ Estate, 2007) ${ }^{6}$ https://en.wikipedia.org/wiki/List of Baileys_Women\%27s_Prize_for_Fiction_winners. ${ }^{7}$ Anna Burns, Milkman (London; Faber, 2018), front cover. Page references in text are to this paperback edition.
} 
The narrator's stalker is referred to as 'the milkman' and later 'Milkman', with 'a capital letter' (197). He steps 'from out of nowhere onto the scene' (2). He drives cars, 'different cars, often flash cars' and a small, white 'shapeshifting' van (3). She wonders where he came from, and why he was 'presuming I didn't mind him beside me when I did mind him beside me?' (6). She does not understand the 'ways that constituted encroachment', nor write her thoughts down, until 'twenty years later' (6), a tiny but important detail which means that there is a disjunction between the moment of stalking (1979) and the moment at which the narrator writes her account of what happened, a slippage in narrative timescale which accounts for McGinty suggesting that the work is set in the 'uneasy 1990s'. 'Twenty years later' brings us to 1999, the year in which the Good Friday Agreement of 1998 came into force. This established what has been described by Patrick Kielty as a 'fragile equilibrium' in Northern Ireland, by normalising security arrangements (including replacing the RUC with the Police Service of Northern Ireland), decommissioning paramilitary groups, and establishing the Northern Irish Assembly (the devolved government of Northern Ireland, which sits at Stormont and comprises 90 Members of the Legislative Assembly). ${ }^{8}$ The Good Friday Agreement acknowledged that the majority of people of Northern Ireland wished to remain a part of the United Kingdom and, furthermore, that a substantial section of the people of Northern Ireland, and the majority of the people of the whole island of Ireland wished to bring about a united Ireland. Crucially, and within certain conditions, the agreement allowed for the people of Ireland to 'exercise their right of self-determination'; and was made possible, in part, by the fact that both Britain and Ireland were members of the EU, a development which had gradually collapsed the economic significance of the border between Northern Ireland and the Republic. ${ }^{9}$ Milkman is set well before these developments, in the era of armed conflict, and a heavily militarised border. 'Middle sister' is stalked 'during the era of not letting bygones be bygones' (25) but she reports and only understands the significance of what happened 'all those years ago' (81), 'years after' (37) in a period which she characterises, with typical barbed irony, as 'the era of psychological enlightenment' (37), namely the era which has followed the Good Friday agreement. There's a bitterness in this narrative perspective, which insists that however

\footnotetext{
8 'Fragile equilibrium' is the phrase used by Patrick Kielty in a remarkable set of twenty tweets aimed at Boris Johnson https://twitter.com/PatricKielty/status/1045782740249890817.

${ }^{9}$ From the 'Northern Ireland Peace Agreement', 10 April 1998. Available at

https://peacemaker.un.org/uk-ireland-good-friday98.
} 
welcome the 'peace process' may be, a sense of ongoing trauma is inevitable for those who lived through the violent civil unrest which preceded it.

That the narrator of this remarkable work is aged eighteen in 1979 suggests an autobiographical correlation between Burns and the world she depicts. At some level she is describing the Belfast of her own youth, and her own experiences. Despite finding her 'reticent about her private life', Lisa Allerdice has established that Burns is Catholic and 'one of seven siblings'.10 Other sources identify the specific geography of Milkman as a fictional reworking of the Ardoyne, the area of north Belfast in which Burns grew up. ${ }^{11}$ The narrator's habit of 'reading-while-walking' is something Burns herself used to do, and she recalls it exciting comment:

I'd go into a shop or a café or a pub and someone would say: 'Oh, you're that girl who walks and reads.' I used to think: 'This is something to comment on?' I wanted to write something about why people would comment on that. ${ }^{12}$

Despite the significance of these autobiographical points of contact, there are some important distinctions to be drawn between the fictional world of the work, and the historic conditions which contributed to its formation. One of these distinctions relates to the moment of the work's composition. Although 'middle sister' reflects that she did not become enlightened and 'have those other thoughts until later... I mean twenty years later' (6), her voice and experience is not necessarily to be conflated with that of Anna Burns, whose record of what she describes as an 'an entire society affected by long-term violence, living under intense pressure' was completed in the Spring of 2014 (or thereabouts), and not at the end of the 'uneasy 1990s'.13 The legislative and administrative changes which the Good Friday Agreement have brought to Northern Ireland have taken years to fall into position, and Milkman, which reflects on the 'Troubles' that preceded those changes, is a kind of deep psychological response which could not be written quickly. If 'looking back in anger and psychological bewilderment'

\footnotetext{
${ }^{10}$ Lisa Allerdice, 'It's nice to feel I'm solvent. That's a huge gift': Anna Burns on her life-changing Booker win', The Guardian, 17 October 2018.

${ }^{11}$ Malachi O'Doherty, 'Man Booker Winner Anna Burns', Belfast Telegraph, 20 October 2018; Catherine Toal, 'Milkman by Anna Burns: Putting Ardoyne on the Literary Map', The Irish Times, 16 October 2018.

12 Burns cited in Allerdice, 'It's nice to feel I'm solvent.', The Guardian, 17 October 2018.

${ }^{13}$ Description of Milkman given by Burns in interview with the BBC, 17 October 2018

(https://www.bbc.co.uk/news/entertainment-arts-45881852); date of completion for the work given by Burns in interview with Alex Marshall, 'The New Booker Prize Winner Who May Never Write Again', The New Yorker, 29 November 2018.
} 
is one way of thinking about the authorial motivation of this work, it is important to note that it is not possible to begin that process until you have at least reasonable assurance that over means over, and that the fragile equilibrium is set to endure. To put it another way, one way of thinking about Milkman is to see it as the record of a moment (the period of stalking, 1979, and that specific moment of the 'Troubles') which has taken an inevitably long period to process and produce.

The question of moment is also significant for the reception of the work. Much happened between 2014, the year in which Burns completed the work, and May 2018, the month in which it was published. Burns became seriously ill, for one thing. As a result of a 'botched operation' she suffers from debilitating lower back and nerve pain, and has been unable to write since completing the work. ${ }^{14}$ The process of securing publication was particularly protracted. Agents failed to get back to her, and publishers turned the work down. According to Paul McVeigh, who interviewed Burns in December 2018, one 'big publisher... said she showed promise and if she sent them $£ 2000$, they'd put her on one of their courses'.15 Eventually David Grossman, a literary agent, became interested in the work, and Milkman was secured by Faber in December 2016.16 It seems likely that Milkman proved difficult to place because the work is not easy to summarise and Burns did not have a high public profile. From Grossman's perspective, it must also have been tricky to 'sell' a book with no character names, no place names, no apparent 'adventure' in the plot, and lengthy digressive paragraphs which demand detailed concentration and engagement. In the end though, Milkman's delay was fortuitous because of a series of events which have shaped the reception of the work in unexpected ways. On 23 June 2016, Britain voted to leave the EU, an event that has put the status of Northern Ireland, its border and recent history back into British cultural and political consciousness. Against a backdrop of general political turbulence and uncertainty, Brexit negotiations have forced attention to the meaning of the Good Friday Agreement, and how the currently frictionless border might be honoured in any future political arrangement. At the same time, there has been considerable political upheaval within the Northern Irish political system. Power-sharing at Stormont, a crucial component in the arrangements

\footnotetext{
${ }^{14}$ Alex Marshall, 'The New Booker Prize Winner Who May Never Write Again', The New Yorker, 29 November 2018.

15 Paul McVeigh, 'Rising from the Shadows', The Irish Times, 15 December 2018.

${ }_{16}$ Date of acquisition given at https://www.faber.co.uk/blog/fabers-editorial-director-louisa-joyner-onacquiring-milkman-by-anna-burns/.
} 
that the Good Friday Agreement made possible, collapsed in January 2017 and despite fresh elections in March that year the two largest parties, the DUP and Sinn Féin, haveat the time of writing (January 2019) - been unable to agree a basis on which to establish regular parliamentary business. Northern Ireland has now passed the international record for the longest period without a functioning government, in what must be seen as a token of how deeply and dangerously divided its political culture remains. In this context, and for readers in Britain and Ireland in particular, Milkman, written during a period of greater political stability but depicting a 'long history of hatred and violence' (336), is a reminder that the 'hair-trigger society' (6) which Burns describes could easily return.

To be eligible for the Man Booker Prize 2018, a work had to be published between 1 October 2017 and 30 September 2018. ${ }^{17}$ The longlist of thirteen titles selected by this year's judging panel-which comprised Kwame Anthony Appiah (academic philosopher and chair), Val McDermid (crime writer), Leo Robson (writer), Jacqueline Rose (literary critic), and Leanne Shapton (graphic novelist) — was announced on 24 July 2018 and the shortlist of six titles followed on 20 September 2018.18 As the judges were deliberating, the news was full of what could, should or might happen to the Northern Irish border post Brexit. It is clear from the judges' comments, particularly those of the chair, Kwame Anthony Appiah, that that news agenda shaped the way they saw Milkman. Here, after all, was a work with a pressing topicality, a work which documented, in forensic detail, the mentalities which shaped Northern Ireland during a recent period of 'great hatred, the great Seventies hatred.' (96) By forcing attention on what had happened in 'the heavily patrolled and fortified units of the statelet' (191), Milkman was encouraging the judges to think about what might happen should a hard border come about as a result of a hard Brexit. Negotiators on all sides wished to avoid this, but news of the ineptly named and vaguely conceptualised 'backstop' did little to allay fears. \#MeToo proved to be

\footnotetext{
17 https://themanbookerprize.com/submissions

18 The longlist comprised: Belinda Bauer, Snap (London: Bantam Press, 2018), Anna Burns, Milkman (London: Faber, 2018), Nick Drnaso, Sabrina (London: Granta Books, 2018), Esi Edugyan, Washington Black (London: Serpent's Tail, 2018), Guy Gunaratne, In Our Mad and Furious City (London: Tinder Press, 2018), Daisy Johnson, Everything Under (London: Jonathan Cape, 2018), Rachel Kushner, The Mars Room (London: Jonathan Cape, 2018), Sophie Mackintosh, The Water Cure (London: Hamish Hamilton, 2018), Michael Ondaatje, Warlight (London: Jonathan Cape, 2018), Richard Powers, The Overstory (London: William Heinemann, 2018), Robin Robertson, The Long Take (London: Picador, 2018), Sally Rooney, Normal People (London: Faber, 2018), Donal Ryan, From a Low and Quiet Sea (London: Double Day, 2018). The six titles which made the shortlist were: Milkman, Washington Black, Everything Under, The Mars Room, The Overstory, The Long Take.
} 
relevant to the moment too. Beginning in October 2017 in response to the allegations against Harvey Weinstein, the \#MeToo movement made historic allegations of stalking, sexual coercion and harassment headline news. Although Milkman was completed before that story had broken, it is clear that the judges valued the work because they thought it helped 'people think about \#MeToo'. Appiah remarked that Milkman is to be commended for giving us a deep and subtle and morally and intellectually challenging picture of what \#MeToo is about.'19 As others have noted, Milkman is 'burningly topical'.20

All of these little details and facts show how reception can be shaped by factors which are not attributable to original authorial intention, and remind us how significant luck and moment are for the making of literary reputation. Burns might have finished Milkman at a different moment, or still be struggling to finish it, or Faber might have decided not to publish it, or they might not have nominated it for the Man Booker. This last possibility - what would have happened to Milkman had it not been listed for the Man Booker-is worth considering, and is certainly something that was considered by those responsible for publishing the work. Writing on Twitter in the immediate aftermath of Burns's win, John Mitchinson, the co-founder of Unbound and presenter of Backlisted, a literary podcast, posted a photograph of a card he had received from Maria GarbuttLucero, Burns's publicist at Faber. ${ }^{21}$ In that hastily written hand-written note-a potent material reminder of the 'personal' and 'behind the scenes' nature of publishingGarbutt-Lucero describes Milkman as a work which 'needs more champions'.22 She continued, somewhat confessionally: 'It is 11 years since Burns' last novel and Milkman is just the kind of book to go untrumpeted in the British press until it gets some awards recognition.'23 These comments proved to be prescient. Before the Man Booker longlisting, Milkman was not reviewed in the broadsheets to any significant extent, and there was only a handful of reviews on the popular digital platforms, Goodreads and Amazon. ${ }^{24}$ In the twelve weeks between the longlisting and the prize announcement of

\footnotetext{
${ }^{19}$ Appiah cited in 'Against the Odds', The Guardian, 17 October 2018.

${ }^{20}$ John Sutherland, 'A Difficult Man Booker Winner Opens Old Wounds', Financial Times, 20 October 2018.

21 https://www.backlisted.fm.

22 Undated postcard from Maria Garbutt-Lucero to John Mitchinson, posted at https://twitter.com/johnmitchinson (October 17 2018)

23 Undated postcard from Maria Garbutt-Lucero to John Mitchinson, posted at https://twitter.com/johnmitchinson (October 17 2018).

${ }^{24}$ Reviews appeared in The Irish Times (12 May 2018), The Guardian (31 May 2018), and The Telegraph (1 June 2018). Goodreads reviews began to trickle in by 8 July 2018; there were just four reviews on
} 
16 October 2018, the reception of Milkman continued to be relatively low key. While profiles and news about other Booker authors appeared regularly in the press, Burns herself, who does not have a significant web presence, was barely cited (with one notable exception, a profile piece which appeared in The Irish Times on 13 September 2018).25 Several of the listed authors participated in readings and events before the prize was announced, but Burns only read at one of the Man Booker events: the authors' evening at the Royal Festival Hall on 14 October 2018. ${ }^{26}$

Without the kind of boost which journalistic coverage and readings can give to a title, there was not a great deal of chatter about Milkman online within what Simone Murray has characterised as the 'digital literary sphere', a particularly significant arena for contemporary book prizes, as she notes. ${ }^{27}$ Meanwhile Faber's publicity team were clearly working hard for another Irish author: Sally Rooney, whose Normal People was published on 28 August 2018, more than a month after it had been longlisted for the Man Booker. Given the unusual fact of Normal People being listed for the Man Booker before the title had even been published, a certain amount of attentive reviewing was inevitable, and it was the role of Faber's publicity department to have help this process. The Guardian published three articles on Rooney within ten days of Normal People being published. ${ }^{28}$ One reader, writing in the comments section of The Guardian thought the level of coverage was 'unfair' and might be seen, collectively, as 'an ad'. ${ }^{29}$ Certainly that reader, whose online soubriquet is 'HaveOneOnMe3', had a point. Kate Clanchy described Normal People as a 'future classic' and praised Rooney's 'underlying faith in fiction itself' while Sian Cain, the Guardian's books site editor, gushed that Normal People-'about coming of age in post-Celtic Tiger Ireland'-'makes being young a drama of universal significance', and speculated that the work might be about to 'enjoy a very abnormal

\footnotetext{
Amazon before the longlisting announcement. The reviews in these sources-goodreads.com and amazon.co.uk-can be sorted by date.

25 'Anna Burns: I had to get myself some distance away from the Troubles', Eoin McNamee, The Irish Times, 13 September 2018.

26 https://www.southbankcentre.co.uk/whats-on/128347-2018-man-booker-prize-readings-2018. Other events associated with the Man Booker 2018 included readings at the Cheltenham Literature Festival (13 and 14 October), Sheffield's Festival of Words (12 October 2018). It seems probable that Burns was reluctant to make multiple public appearances because of her illness.

27 Simone Murray, The Digital Literary Sphere: Reading, Writing and Selling Books in the Internet Era (Baltimore: Johns Hopkins University Press, 2018), 86.

28 The three reviews were: Julie Myerson, 'Normal People: Book of the Day' The Guardian (26 August 2018); Kate Clanchy, 'Normal People: Book of the Week' The Guardian (1 September 2018); Sian Cain, 'Normal People Unites Critics in Praise: Man Booker Prize' The Guardian (1 September 2018). A fourth commendation of Rooney by Sian Cain appeared in The Guardian (5 September 2018).

${ }^{29}$ https://www.theguardian.com/books/2018/sep/01/normal-people-sally-rooney-review\#comments.
} 
prominence' (a clear Booker tip). ${ }^{30}$ Normal People is interesting, moving and wellwritten, and, as a 'huge word-of-mouth hit', did not need the PR department to come out with quite such force. ${ }^{31}$ Rooney, who was born in 1991, appears to have been the beneficiary of what John B. Thompson describes as 'Wylie's Iron Law', an effect associated with Andrew Wylie, an attentive and aggressive literary agent who has argued that 'the only thing that will ensure that a publisher gets behind a book and publishes it energetically is the size of the advance they pay: the more they pay, the more they will get behind the book'.32 Faber outbid six other publishers for the rights to Rooney's first novel, Conversations with Friends (2017) and, as part of a two-book deal, clearly wanted Normal People to be a success. ${ }^{33}$

Hopes were high and plans were in place in the days leading up to the Booker shortlist announcement of 20 September 2018. Oxford's Blackwell's had a huge and eyecatching display of Normal People at the ready. In a sign that the book industry has learnt something from YouTube, the display even included merchandise designed to complement the artwork of the dustjacket, and extend its reach: products included a mug, a canvas bag, a handmade letterpress print, free bookmarks and postcards. ${ }^{34}$ Digital marketing was playing a role too. In the early days of September 2018, Faber's official twitter feed (@FaberBooks) featured several plugs for Normal People, including a gif (a digital flip-book through various images or 'graphics interchange format') which placed citations from the reviews against the colourways of the dustjacket ('There's nothing normal about Rooney. She's exceptional.; 'Hands-down this Autumn's must-read.'; 'Extraordinary.'; 'The best novel published this year.'; 'A beautiful blazing love story.'). ${ }^{35}$

Meanwhile Milkman languished in the shadows. No one thought to compare the rather different fates of Sally Rooney and Anna Burns, and the similarities and dissimilarities between the two titles. Both works are 'coming of age' narratives rooted

\footnotetext{
30 Kate Clanchy, 'Book of the Week' The Guardian (1 September 2018); Sian Cain, The Guardian 1 September 2018 and 5 September 2018.

31 Sian Cain, 'Sally Rooney's Normal People named Waterstone's Book of the Year, The Guardian 29 November 2018.

32 John B. Thompson, Merchants of Culture: The Publishing Business in the Twenty-First Century (London: Polity, 2nd edn, 2012), 69.

33 Martin Doyle, 'Sally Rooney and Liz Nugent sign big book deals', The Irish Times, 15 September 2016; see also Natasha Onwuemezi, 'Faber bags 'intimate' author after seven-way auction', The Bookseller, 15 September 2016.

${ }^{34}$ By purchasing merchandise of this kind readers 'morph into co-marketers', as Murray notes in The Digital Literary Sphere (69).

35 https://twitter.com/FaberBooks (11 September 2018).
} 
in a certain kind of Irish historical specificity-Dublin and the West of Ireland between 2011 and 2015 in the case of Normal People, and, as noted, Belfast in 1979 in the case of Milkman. The generation gap between the two authors is significant: Burns left Belfast in 1987 and had settled permanently in England before Rooney was born. The 'Troubles' which Burns depicts with such compelling insistence are beyond the living memory of millennials such as Rooney, and do not feature in her characters' lives. Both works might be rather blandly categorised as 'by an Irish woman' and 'about Ireland', but, in terms of both style and narrative strategy, it is hard to imagine more different novels, or more different kinds of reading experience. Rooney's work is an accomplished and pacy description of late adolescence and student life which can be read in a matter of hours, whereas Burns's work demands to be taken at a slower pace, and yields its significance more slowly.

This, perhaps, is the reason why Burns made the shortlist and Rooney did not. Or perhaps the five Booker judges, who, after all, are only making a judgement, felt alienated by the hype around Normal People and came to resist the work as a result. Or perhaps they felt that they could not shortlist two novels by Irish women. Published comments by Val McDermid make it clear that a list which expressed a balance of diversity in terms of nationality, gender and ethnicity was something to which the panel aspired. ${ }^{36}$ Two Irish novels in a list of six might have seemed unrepresentative for an award which prizes itself on being 'the leading literary award in the English-speaking world.... awarded to what is, in the opinion of the judges, the best novel of the year written in English and published in the UK'. ${ }^{37}$ Normal People has since gone on to win several awards, among them the Costa Book of the Year, the Waterstone's Book of the Year and the An Post Novel of the Year (for which Milkman was also listed). But, in the Booker shortlisting of September 2018, Normal People lost out to Milkman, much to the consternation of many 'normal people' who follow the Man Booker on twitter ('so sad that the Booker has lost its edge'; 'actually OUTRAGED that Normal People didn't make the Booker cut') ${ }^{38}$ In the

\footnotetext{
36 See Craig Simpson, 'Man Booker Judge says Prize not about age', Irish Independent, 20 September 2018 which cites McDermid ('We didn't tell each other that we need to have more balance or diversity.'). See also Val McDermid, 'The Inside Story of Judging the Booker Prize', The Guardian, 17 October 2018 and Alex Marshall, 'Q. \& A. Val McDermid on What It's Like Judging the Man Booker Prize', New York Times, 14 October 2018. All three sources emphasize the fairness and cordiality of the judging process in 2018. 37 Description of the Man Booker Prize from https://themanbookerprize.com/fiction/about. ${ }^{38}$ https://twitter.com: Rebecca Nicolson (20 September 2018); Leaf Arburthnot (20 September 2018). Many tweeters recorded their disappointment at this decision.
} 
run up to the shortlist announcement, Faber's twitter feed had barely mentioned Burns and quickly responded with two tweets. The first directed readers to an excerpt from the remarkable audio-book version of Milkman read by Bríd Brennan, a highly accessible means of getting into the story; the second was a gif featuring the artwork of the dustjacket and snippets from the reviews ('original, funny, disarmingly oblique and unique'; 'a potent and urgent book'). ${ }^{39}$

\section{The Technique of Milkman}

The Man Booker judges read the shortlisted works three times, and as McDermid has suggested, this places a particular demand on the text: 'a book that stands up to being read three times is a book that probably has a claim to being the best of the year, not just something that's a pretty magpie thing'.40 The language of Milkman is something they particularly valued, and found to be 'surprising and immersive'. ${ }^{41}$ Appiah, for example, commented on 'the distinctive and consistently realised voice of the funny, resilient, astute, plain-spoken, first person protagonist... her words pull us into the daily violence of her world'. ${ }^{42}$ Burns has a particular interest in narrative technique, something she has noted in recalling her younger self, reading-while-walking on the Berwick Road in Ardoyne: 'I remember thinking, but how did that writer do that? How did he do that?'. ${ }^{43}$ The language which the narrator uses is key to the achievement of Milkman as a whole: the particular lexical choices which Burns makes enable her to communicate the character and mentality of 'middle sister', and to deconstruct the mentalities and structures of Northern Irish society as it was before the Good Friday agreement. In essence middle sister's lexicon blends three separable elements:

(1) words, names and descriptions which are unique to the perspective of 'middle sister' such as 'Somebody McSomebody', 'renouncer', 'maybe-boyfriend', 'stalk-talk', the 'shiny people', etc;

\footnotetext{
${ }^{39}$ For the tweet about the Audible see https://twitter.com/FaberBooks $(20$ September 2018). A longer excerpt can be sampled at https://www.audible.co.uk/. For the gif see https://twitter.com/FaberBooks (21 September 2018).

40 Alex Marshall, 'Q. \& A. Val McDermid on What It's Like Judging the Man Booker Prize', New York Times, 14 October 2018.

${ }^{41}$ https://themanbookerprize.com/news/anna-burns-wins-50th-man-booker-prize-milkman.

42 https://themanbookerprize.com/fiction.

43 'Anna Burns: I had to get myself some distance away from the Troubles', Eoin McNamee, The Irish Times, 13 September 2018.
} 
(2) words, phrases and syntactical structures which record, play with and build upon the particular linguistic features of HibernoEnglish, such as 'wee' as in 'wee sisters', and 'beyond the pale' and inversions such as 'would you not', etc;

(3) words and descriptions which more neutrally model the features of the frighteningly dysfunctional and violent world in which the action takes place, such as 'partisan', 'military intelligence', 'plainclothes people', and 'anti-personnel devices'.

All three of these linguistic elements are blended in the narrator's voice, a unique and singular voice which is 'consistently realised' as Appiah notes, and is one of the work's conspicuous strengths. But it is also the reason why some readers, longing for relief from a voice which they may not be able to easily or completely follow, despair, give up and claim to find Milkman 'baffling' and 'brain-kneading'.44 Any novel which is told from a first-person point of view asks that readers accept the value, logic and coherence of that viewpoint (or detect its unreliability). Milkman offers a story which is told, as Laura Miller has observed, 'in an unspooling, digressive and fretfully ruminative manner that bears a rough semblance to stream of consciousness but is much easier to follow'.45 'Stream of consciousness'-a 'mode of narration which undertakes to reproduce... the full spectrum and continuous flow of a character's mental process, in which sense perceptions mingle with conscious and half-conscious thoughts, memories, expectations, feelings and random associations'-would be difficult to sustain over a whole novel. ${ }^{46}$ From a narrative perspective, Milkman blends a stream of consciousness style (passages of memory, thought, and apparently random associations) with a more conventional first person narration, which is focussed on telling the story of what happened to 'middle sister' during the few months in 1979 when she was stalked. ${ }^{47}$ This 'story' element-the 'real time' of the novel's major plot line-is complicated and thickened by the narrator's

\footnotetext{
${ }^{44}$ Claire Armistead, 'Milkman is a Bold Choice', The Guardian, 16 October 2018, https://www.theguardian.com/books/2018/oct/16/milkman-is-a-bold-choice-but-its-unlikely-toplease-booksellers.

45 Laura Miller, 'A Novel about Coming of Age Amid the Troubles', New Yorker, 10 December 2018, https://www.newyorker.com/magazine/2018/12/10/a-novel-about-coming-of-age-amid-the-troubles. ${ }^{46}$ M. H. Abrams, A Glossary of Literary Terms (London: Harcourt Brace College Publishers, [7th edition], 1999), 299.

${ }^{47}$ Milkman is a classic first person narration in that the narrator's point of view is limited; middle sister only attempt to tell what she knows, can infer or find out from talking to other characters.
} 
digressions into the traumatic events of the recent and not so recent past. These include, for example, the discussion of the narrator's father's 'crawling along to the grave type of depressions' (85); the 'great canicide' which happened when the narrator was nine and involved 'the soldiery from over the water' who 'slit the district's dogs' throats in the middle of one night' and left the 'dead bodies in a giant heap' (94); the history of what happened to the area's 'international women's group' (153); and the story of the narrator's brother's funeral when three uniformed gunmen 'appeared speedily out of nowhere and fired a volley of shots over his grave' (130). Readers might struggle to understand the connection between the 'plot' elements and the more lengthy digressions, but it is worth persevering because the different elements are made to cohere extremely effectively in the closing chapters of the novel which, taken as a whole, might be read in three ways. First, Milkman is an indictment of how vulnerable people, particularly children, suffer in the face of extreme violence; second, it is an analysis of the psychological impacts of harassment; and third it provides a carefully observed anatomy of Northern Irish society in the 1970s.

Names-first names, surnames-played a particularly important role within that society, and the narrator's approach to naming is one of the distinctive features of her lexicon. This is apparent from the very first sentence which announces the death of 'the milkman', and the normality of violence and intimidation in the narrator's community:

The day Somebody McSomebody put a gun to my breast and called me a cat and threatened to shoot me was the same day the milkman died. (1)

'Somebody McSomebody', the narrator's name for this character, suggests the world of the large Irish family, of people knowing the 'clan' but not the individuals, and of not caring to single out who is who. 'Mc' or 'Mac' as prefix simply means 'son of' and thus this character is simply 'somebody the son of somebody', a nimbly ironic detail which suggests patriarchal dominance. Apart from Lassie, the family dog, the narrator does not give anyone a proper character name. Every character is described, instead, by their relation to her. The reason for this relates, in part, to family structure. She is one ten children, and her father could never remember the names of his children 'not without running through a chronological list':

Sooner or later, by running through, he'd hit on the correct one at last. Even that though, became too much and so, after a bit, he dropped the mental catalogue, opting instead for 'son' or 'daughter' which was easier. And he was right. It was 
easier which was how the rest of us came to substitute 'brother' and 'sister' and so on ourselves. (55)

Thus the many brothers and sisters are named by their birth position, with 'middle sister' (the narrator) being so named because she is the fourth of seven girls with three 'wee sisters' below her.

This system of naming is part of an authorial strategy which makes the world depicted in Milkman menacing, as Burns herself has observed. ${ }^{48}$ Character names are culturally specific; they are usually part of a narrative foregrounding which help to locate a story. By omitting individual and specific character names, and reducing characters to names which specify their function in the community and relation to the narrator-ma, da, first brother-in-law, eldest sister, longest friend, tablets girl, nuclear boy-Burns is deliberately taking away some of the cultural specificity of the world she describes. This has two impacts. For readers familiar with the Northern Irish context, Burns is making it strange in order to force a reconsideration. For others, for whom the book is less obviously 'about' the Troubles, the work speaks a more universal truth, and is applicable beyond the Irish context. Neither of these readings excludes the other, of course, and the lexicon of the work has an important role to play here, with the narrator's tactic of 'not naming' suggesting the work's universality, and the Hiberno-English of phrases such as 'over the water' and 'beyond the pale' seeming to insist on the work's cultural specificity.

The preoccupation with names recurs throughout the work. In a passage of heavy irony and humour, the narrator describes a local couple who keep 'the list of names that weren't allowed in our district... not allowed for the reason they were too much of the country 'over the water" $(22,23)$. 'Lance, Percival, Wilbur, Wilfred, Peregrine, Norman' are among the 'banned' English names included in a litany in the text (23). The narrator's name is never revealed but, in another menacing touch, is used by a few people she knows, at particular moments of duress-such as when she is being threatened in the toilets by the 'groupies' ('They said my name then, my first name, thereby crossing over and shunning the interface.', 127), and when she is chatted up by McSomebody who wants her to 'leap into his arms' ('here he said my name, my first name', 131). But the clinching detail of naming as a leitmotif in the text is hidden in the joke of the title: Milkman. There are, in fact, two milkmen in the novel: 'real' milkman who actually delivers milk and falls in love with ma, and 'milkman', the narrator's stalker, who does

${ }^{48}$ https://www.channel4.com/news/anna-burns-on-her-man-booker-win. 
not deliver milk. The puzzling enigma of his name is solved in the final chapter of the work in the news reports of his death which reveal that: 'Milkman's name really was Milkman' (304). Certainly this unusual English language surname-'but when you think about it, why was that weird? Butcher's a name.'-is not approved by the 'guardians of the names' (304). But Milkman is a real surname, and there are families in Northern Ireland with this surname. Truth is stranger than fiction, as Burns knows.

The complete omission of place-names is another notable feature of the narrator's lexicon. There may be a consensus that Milkman is 'about' Belfast, but the city is never named. Instead, its geography is implied in a string of references to interface roads ('sad and lonely' roads which 'ran between the religions'), and 'staunchly no go areas'. In chapter three, middle sister describes her walk home from 'downtown', a walk which includes going through a 'bleak, eerie, Mary Celeste little place... dominated by three giant churches'. This is the 'ten minute area... a ghostly place that you simply had to get through' (82). The narrator navigates through with speed, noting 'seven landmarks that peripherally I'd tick off in my head as I read my book' (82). These include the police barracks, 'the holy women's house', the parks and reservoirs, and 'the cemetery which everybody, including the media, the paramilitaries, the state forces - even some postcards - termed 'the usual place'.' (82) The sense of Belfast which emerges from such details is very strong and points to an interesting disjunction between the physical form of the book, and its written element. The dustjacket, approved by Burns, shows an atmospheric photograph of Belfast Lough in the sunset at low tide, with the docks and Cave Hill in the distance. ${ }^{49}$ The picture credit does not specify the location but for those who recognize this landscape, the paratextual detail of this image has the effect of specifying and confirming the setting at an early stage in the reading process, even if the niggling question of why Burns omits place-names persists. For other readers who do not detect that the image on the cover is Belfast the setting remains more open, and a less pressing question. Burns's point, after all, in taking away all that might root the story in a specific place is to suggest that the events she is describing could happen in any repressive militarised society where conflict continues. The anonymity of the setting means that the work can transcend the conditions of its making in order to speak a more universal truth. Here it is worth bearing in mind that Milkman has been a particular

\footnotetext{
${ }^{49}$ Comments by Anna Burns, Royal Festival Hall, 14 October 2018.
} 
international success, with the deal for 'simplified Chinese rights ... believed to be the biggest single deal ever done for an author not previously published in China'. ${ }^{50}$

Yet there is so much in the lexicon of the work to remind readers of the Irish literary tradition, and particularly a writer like J. M. Synge, who is casually and knowingly referenced in middle sister's comments on the adult evening class 'littérateurs' who go 'to the theatre with pens, flashlights and little notebooks to watch and critique Playboy of the Western World.' (73) The irony in this remark is that Burns has clearly learnt something from Synge's example, namely the use of Hiberno-English for literary effect. Writing in 1907, in the preface to The Playboy of the Western World, Synge claimed that his writings:

got more aid than any learning could have given me from a chink in the floor of the old Wicklow house where I was staying, that let me hear what was being said by the servant girls in the kitchen.

His lexicon, by his account, is 'rich and living... among the country people of Ireland'.51 Though a first person narrative, Milkman contains a good deal of reported speech, and Burns has an acute ear for differentiating character and gender through the judicious placing of appropriate and authentic phrasing. For example, while seated in the upstairs lounge of 'the district's most popular drinking-club' longest friend asks middle sister: 'tell me, what's the crack with you and Milkman?' (197). 'Crack', used in this position, means news or gossip, and derives from Middle English crak, but also exists in Irish as 'craic', though it may be 'pseudo Gaelic'. ${ }^{2}$ Whatever the case, it is a conspicuous Hibernicism which reflects on the fact that English as spoken in Ireland includes words, phrases and formations which derive from the Irish language, even when it is used by speakers who have no knowledge of Irish (like middle sister who describes Irish as 'my native language which I didn't speak', 43).

Middle sister is actually learning French and thinks about language quite precisely. For example in chapter 2 she considers some of the euphemisms and phrases used by 'maybe-boyfriend's friends about his troublesome neighbours' (33). These include 'Cunning-boy-ballocks. No offence or anything but. I'm only sayin' but. No harm to you like but.' (33) The sense of energy and authenticity in these phrases-which

\footnotetext{
${ }^{50}$ Heloise Wood, 'Astonishing Demand for Milkman Continues', The Bookseller, 21 November 2018. 51 J. M. Synge, Preface to The Playboy of the Western World, edited with notes and introduction by Ann Saddlemyer (Oxford: Oxford University Press, 1995), 96.

52 https://en.wikipedia.org/wiki/Craic
} 
communicate the world of aggressive and thrusting adolescent men in a group-is suggested by the way in which they replay through the narrator's mind, and is underlined by the use of italics. Reported phone conversations provide another narrative opportunity in which 'overhearing' plays a role. While confined to the bed after being poisoned by 'tablets girl', middle sister overhears a conversation in the hallway between ma and third brother-in-law, an exercise fanatic who wanted to know 'why I was not going running.' (243). Third brother-in-law is slow to pick up on details and hints, and while on the phone, ma whispers to the wee sisters:

The boy makes no sense. Funny wee being. Then again, that whole family's funny. God knows why your sister married into it. (244).

There is a dry humour and authenticity in the conversation which ensues, which includes third brother-in-law saying 'tell her she knows where to find me when she comes to her senses. Meanwhile, I'm away on here to run by myself' and ma replying: 'Okay son... as it is, she's nearly dead so I'm keeping her in bed yet.' (244). The leave-taking at the end of this long conversation-part of a leitmotif in the novel which comments on the culture of phone use in the 1970s-is also highly achieved:

they said goodbye which took another five minutes because kind people here, not used to phones, not trustful of them either, didn't want to be rude or abrasive by hanging up after just one goodbye in case the other's leave-taking was still travelling its way, with a delay, over the airwaves towards them. Therefore, owing to phone etiquette, there was lots of 'Bye', 'Bye', 'Goodbye, son-in-law', 'Goodbye, mother-in-law', 'Goodbye', 'Goodbye', 'Bye', 'Bye' with each person's ear still at the earpiece as they bent their body over, inching the receiver ever and ever closer on each goodbye to the rest of the phone. (244)

For all his protestations of authenticity, Synge's lexicon is clearly dramatic. You have to be on the stage, like Christy Mahon's father, to use a phrase like 'an ugly young streeler with a murderous gob on him'.53 A similar intensification of the authentic patterns of Hiberno-English can be observed in Milkman. In the milkman's first reported speech-spoken on an occasion when he has succeeded in somehow slowing the narrator's regular run to a walk because she has not known how to rebuff his unwelcome

${ }^{53}$ Synge, Playboy of the Western World, 125. 
advances - a sinister edginess is communicated through the addition of ' $a$ ' in front of standard verbs. The total effect is chilling:

'Not sure,' he said, 'about this arunning, about all of that awalking. Too much arunning and awalking.' With that, and without another word, he went round a corner at the edge of the parks and disappeared. (9)

Though Hiberno-English is full of deviation from standard forms, 'arunning' and 'awalking' are not standard within its lexicon. This departure from the linguistic norm is a kind of stage Irish which heightens the drama, and the sense of menace which Burns wants to communicate. Hiberno-English often reverses expected word order, and Burns takes this trait and intensifies it in order to suggest the very complicated ways in which middle sister thinks. Thus the narrative contains phrases like 'Never will I tell you, ma', and 'Completely therefore, was I thrown by this new line of talk.', and 'I could see my legs, see the ground, but impossible it was to get a connection with them.' $(45,105,296)$ These convolutions in the lexicon reflect the narrator's increasing confusion as the stalking intensifies, and she becomes more silent, withdrawn and psychologically disturbed.

Even so there are elements in middle sister's use of language which suggest her continuing resilience and perspicuity. One of the remarkable achievements of this book, and of middle sister's narration, is the way in which it anatomises the 'Troubles' while shunning its ordinary lexicon, a lexicon which includes words and phrases like the Six Counties, the Orange Order, the border question, the peace wall, the Loyalists, the Provos, the Republicans. ${ }^{54}$ Middle sister refers to the IRA and all of its associated splinter groups as the 'renouncers-of-the state' and the UDA and other loyalist paramilitaries as the 'defenders-of-the-state'. The persistent use of these invented terms-her own unique lexicon for describing the paramilitary situation in Northern Ireland-is a neat and ironic means by which she suggests her estrangement from the community in which she lives, and her distaste for everything that community values. 'Renouncer'-her coinage for one who does not accept the validity of the state's legitimacy over the community-is a word and concept reiterated throughout the text. There are references to: the 'renouncers' known and unknown associates', 'reputed to be renouncers', 'paramilitary renouncers', a 'renouncer of the state bomb', non-renouncers, 'renouncer-snipers', the 'enemyrenouncer commandery', 'a renouncer atrocity', 'top renouncer intelligence gatherer',

\footnotetext{
${ }^{54}$ For a glossary of terms related to the conflict and politics in Northern Ireland see http://cain.ulst.ac.uk/othelem/glossary.htm\#U
} 
'old school renouncers', 'the district renouncers', 'the renouncer ladder of rank', 'female renouncers', 'renouncer-wives', 'renouncer blood credentials', 'renouncer-in-fantasy', 'renouncer kangaroo-court', a renouncer-run chapel hutment'. The word becomes more powerful by dint of its repetition, and makes Burns's vision and irony more complicated. Other words which Burns uses to describe the context are without local 'colour', and are, in the main, the words which were used in news reports and more general discussions of the Troubles in their time: collusion, informership, over the border, state-forces, communal policing, partisan police force, accessory, undercover squads. Burns's aimin a creating a unique lexicon which fuses her own coinages with colloquialisms, euphemisms, and a kind of stretched and heightened Hiberno-English-is to make the familiar strange and thus force a reconsideration of the kinds of things which happened in Ireland at this time.

But the impact of Milkman stretches well beyond that initial and foundational context, and invites readers who may pay little attention to the specific and rooted historicity of the setting. Milkman is a bildungsroman which focuses, in the end, on how middle sister resolves her difficulties and develops. Milkman—the 'chilling, sinister, paramilitary' —is killed by the 'state forces', which means:

no more having to watch my back, expecting to turn a corner to have him fall into step with me, no more being followed, being spied upon, photographed, misperceived, encircled, anticipated. No more being commanded. (302)

Somebody McSomebody, middle sister's more 'amateur stalker' gets his come-uppance too. He is beaten up by the 'groupies' for showing disrespect to women, and is 'had up at a kangaroo court.' (310) In face of these developments, middle sister is able to reappraise how she has responded to the experience of being intimidated. She recognizes her mistake in failing to speak up about the 'encroachment upon me by the milkman'; and realises, as she restarts her regular running sessions with her endearing third brotherin-law, that 'people in this place did give a fuck.' (346) In a society where 'violence was everybody's gauge for judging those around them' (2), one of the difficulties middle sister has confronted is a difficulty with knowing how to 'push for clarification' (115) in the face of milkman's unwanted attentions. The situation described is one of genuine psychological terror owing to Milkman's threats to kill maybe-boyfriend ('he had pretty much spelled it out for me: death by carbomb', 115). It is also a situation of deep 
uncertainty because the narrator does not fully understand 'disguised sexual jealousy' or what 'is underlined by this milkman in the subsoil of our conversation.' (115) Nor can she define 'this stalking', as she explains in a clinching moment:

Hard to define, this stalking, this predation, because it was piecemeal. A bit here, a bit there, maybe, maybe not, perhaps, don't know. It was constant hints, symbolisms, representations, metaphors. (181)

But Burns, a separable presence from 'middle sister', has understood the slippage between what is casual, explicit and intended in conversation. Milkman is a remarkable work-and a remarkable and worthy winner of the Man Booker-because it records the voice of someone who has struggled to find that voice. It is a subtle novel which can be read within and outside the Irish tradition, and is timely and important because of the emphasis it places on the realities of what it is like to be formed within a situation where violence, corruption and instability are the norm, and stalking, coercion and sexual harassment creep under the radar.

24 January 2019 